\title{
Rethinking Agency and Resistance What Comes After Girl Power?
}

\author{
Marnina Gonick \\ Emma Renold \\ Jessica Ringrose \\ Lisa Weems
}

\section{Introduction}

With the current proliferation of images and narratives of girls and girlhood in popular culture, many 'truths' about girls circulate with certainty. Amongst the aims of this Special Issue is to examine critically these 'confident characterizations' (Trinh 1989), to trace the social conditions which produce these 'truths' along with the public fascination with girls and to analyze critically the effects of these 'truths' in the lives of young girls. The concepts of resistance and agency have been critical to the field of youth studies, sociology of education and school ethnographies (Hall and Jefferson 1976; McRobbie 1978; Willis 1978) for conceptualizing the relationships between young people and their social worlds. Ground breaking scholarship by McRobbie (2000) challenges the gendered assumptions of political agency articulated in previous theories of subcultures developed in the 1970s and 80s. While feminist poststructuralist work in the 1990s has re-conceptualized agency in ways that are markedly different to humanist notions of rational actors with free-will (Butler 2006; Davies 2000), feminist researchers have also shown the importance of a classed, raced and sexed analysis of agency. For example, scholarship by feminists of color have shown how girls of color challenge and defy dominant stereotypes of girlhood in culturally specific ways such as participating in spokenword contests, rap and hip hop, and 'beauty contests' (Hernandez and Rehman 2002; Gaunt 2006). In the changing social, economic, political and globalizing context of the new millennium, where 'girl power' has become a marketing tool and a branding (Klein 2000) of girlhood, it is important to look anew at the relations between girlhood, power, agency and resistance. 
In an important sense, we are already in an 'after girl power' period, and have been for some time. In posing the question, "What comes after girl power?" as the organizing framework of this special issue, we are less interested in unveiling a successor discourse than we are in using the question to ponder new approaches to conceptualizing agency and resistance in Girl Studies. That new-perhaps more complex and nuanced-approaches are required is evident in the rapidly changing social, economic, political and global media contexts emerging out of neoliberalism and what Gill (2007) has called a post-feminist sensibility.

Neo-liberalism and a post-feminist sensibility are closely connected in that neo-liberalism insists on the individual as a rational self-reflexive 'agent' constructing a lifelong 'choice' biography (Davies and Bansel 2007). Concomitantly, a post-feminist sensibility and political discourse problematically dismisses sexism as an on-going feature of contemporary life in the West (Gill 2008; Taft 2004; McRobbie 2004). Girls and women are constructed as the ideal rational actors who have succeeded in re-inventing themselves, adapting to shifting global market forces as the new reflexivity winners in educational achievement and employment. The effects of neo-liberal discourses individualize and depoliticize and have enabled post-feminist discourses to thrive, since the individualizing, fragmenting logic works to destabilize collective movements like feminism. The 'Girl Power' in the title of the Special Issue, is therefore, a heavily contested pair of signifiers (Gonick 2006) signaling a discourse that is embroiled in a post-feminist narrative of women's and girls' successes that works to render continuing gendered/sexual inequalities largely invisible (McRobbie 2008). While girl power emerged within the economic, socio-political context of the 1990s where girls could be active, in the 2000s they are now expected/demanded to be fully self-actualized neo-liberal subjects. However, the constraints of heteronormative white femininity are also firmly entrenched, though not necessarily in exactly the same old versions. Herein lies the paradox that underpins depoliticized notions of agency and girl power: girls are still bound by the body and sexual difference (Braidotti 2006). Writing from a cultural studies framework about representations of girls and women, both Gill and McRobbie argue that agency needs to be specifically re-theorized in relation to new formulations of gendered and sexual politics and discourses. As Gill suggests, "for young women today in post-feminist cultures, the display of a certain kind of sexual 
knowledge, sexual practice and sexual agency has become normativeindeed, a 'technology of sexiness' has replaced 'innocence' and 'virtue' as the commodity that young women are required to offer in the heterosexual marketplace" (2007: 72). McRobbie (2008) has a similar analysis of what she calls a "post-feminist masquerade" in which girls and women living in neo-liberal societies are to balance masculine qualities of phallic power with renewed pressures around hypersexualized visual display and performances of normative femininity.

We argue that girls are confronted with discourses of girl power, which are obviously culturally and contextually contingent, with highly unequal effects. For example, in 'third world' societies discourses of girl power are seized upon as Millennium goals to promote development. Thus, we suggest that in the context of globalization any understanding of girlhood and agency involves an analysis of the inter-related and asymmetrical relations of power in the movement of people, information, cultural productions and capital. Whether or not the articles in this Special Issue directly address issues of globalization, many take into account and/or challenge policies, identities, practices, laws and customs that constitute normative views of girlhood in national and international contexts which privilege a model of 'West vs. the Rest'. In the context of discussing post-feminist liberal individualism, Rosi Braidotti argues that diversity and difference in globalized cultural economies have become valuable, marketable commodities with globalization functioning through the incorporation of Otherness. Drawing on Deleuze and Guatarri's ambitious work, Capitalism and Schizophrenia Vol. 2, A Thousand Plateaus (1980), Braidotti (2006) conceptualizes this paradoxical "simultaneous displacement and refixing" of binary oppositions (e.g. masculine/feminine) as "one of the most problematic aspects of contemporary political culture" (49). She argues that it engenders, propels and contains simultaneously opposite effects-degrees of gender equality with growing segregation of the sexes, resulting in gender trouble on the one hand and polarized sexual difference on the other.

To illustrate these simultaneously oppositional effects, Renold, Ringrose and Epstein (2009) draw on US Katy Perry's no.1 hit song, I kissed a girl because it captures this schizoid dynamic. Here they see discourses of girl power and post-girl power through ostensibly queerchic lyrics and the simultaneous disruption and fixity of heterosexual femininity/or 'girl-ness'. For example, in her lyrics, Perry takes up the 
'masculine' position of sexual aggressor ("I kissed a girl") through the 'hot lesbian' motif (Gill 2008). Here she is up for anything yet there is an element of surprise at her own sexual pleasure: "And I liked it!". This confident queer/porno chic sexual performance is immediately reterritorialised with a regulatory normative heterosexual script of feminine passivity and obedience: "I hope my boyfriend don't mind it".

This multiple and contradictory terrain of masculinity and femininity, agency and accommodation, and global and local articulations demands that new questions be asked or that old questions be asked anew. How might agency and resistance be imagined and analyzed within and against the signifiers of 'girl power,' 'post-feminism' and 'globalization'? If discourses of agency and resistance are continually commodifed by the capitalist machine, what does this mean for a feminist notion of political (Kennelly 2009), critical (McRobbie 2008) agency? What does resistance look like? How do we identify it? Where do the possibilities for resistance lie? What kinds of global exchanges are taking place with respect to the formation, transmission and circulation of new discourses of girlhood? What is the relationship between girls, agency and neoliberal policy? In what ways do girls resist new and old discourses of femininities and their intersections with other discourses of race, ethnicity, sexuality, ability etc? How is girls' resistance and agency represented in popular and alternative cultures? How do girls themselves use cultural production as a mode of resistance? Thus, rather than connote the end of a project, the question "What comes after girl power" is meant to bring to the surface the possibility that multiple and concomitant strategies of analysis are required in a time of dense convolution. This Special Issue highlights the complications and tensions of producing cultural analysis when representations of girls and girlhoods are swiftly shifting, and where sites and contexts in which girls' subjectivities are negotiated and lived are both emerging and disappearing.

\section{Agency and Resistance in Girl Studies}

Since we are suggesting that new times call for new strategies for conceptualizing agency and resistance, it is also important to re-visit briefly the ways in which agency and resistance have been taken up in the field. The concepts of agency and resistance are central to girlhood studies 
as they have been for youth and cultural studies more broadly. Much of the current analyses continue to draw and build on theorizing that emerged out of the UK Gramscian tradition of Raymond Williams and Stuart Hall (Corrigan 1979; Hall and Jefferson 1976; Hebdige 1979; Willis 1977). In this view culture must be viewed not as a given set of relations and ideas structuring social life, but as something that is produced through human intention and action. Thus, culture is understood through what people $d o$, not, as more structural approaches would have it, through the symbolic or economic calculations assigned to them. The emphasis is on how the structure is produced, reproduced and transformed through human agency. Understanding this dynamic relation assists us to understand why people consent to oppressive rule and under what circumstances they resist. In exploring the relationship between consent and coercion, Gramsci recognized the role of culture in manufacturing consent-in permitting the exercise of control in the absence of violence. He theorized that it is in the domain of culture that economic and political 'persuasions' become inserted into the moral universe and get taken up by individuals as common sense. People consent to rule when they accept as given (or at least desirable relative to perceived alternatives) the values, norms, and versions of justice supporting the existing distribution of goods and identifying the permissible range of dissent. They resist when they recognize the arbitrary foundations of rule. Individual practice thus expresses a tenuous relationship between and among consent, domination and resistance.

As Angela McRobbie (1978) notes in one of the earliest published articles about girls' relation to youth culture, at this time researchers sought to use this critical perspective to analyze subcultures and style of working class youth. The focus of much of this research was on the possibilities of finding forms of resistance within young people's everyday engagements with popular and consumer culture. McRobbie theorized that what had been read as young women's conformity to the femininities of the market-place might be understood alternatively. She suggested that their loud talk in classrooms about make-up and fashion signified their valuing of working class femininity, their mothers and the home over the middle-class values of the school. Focusing on their abilities to turn around and subvert consumer culture for subversive purposes, work of this kind seeks to give value and meaning to the subversive strategies, the ways of 'making do' of young, often marginalized, people. 
Re-examining this analytic strategy from the vantage point of close to thirty years later, in her recent book McRobbie (2009) suggests that this approach has become too separated from its initial efforts of examining the dynamics of agency and constraint. Although McRobbie does not elaborate, it seems that what has fallen away in recent theorizations of girls' and women's agency and resistance is the Gramscian framework that takes individuals' actions as its object of analysis, but only in relation to the material circumstances and dynamics of power within which they live. She questions the celebratory dis-articulation of individualized girls and women from capitalist power relations and consumer culture. She asks, "Just how oppositional were these seemingly subversive practices?" "What value did they deliver to women in the context of the relations of power and powerlessness within which they still found themselves inscribed?" (2009:3).

In posing the question "what comes after girl power?" we suggest that girls' agency and resistance needs to be theorized as articulated and evidenced within the logic of the production of gender, the body, and sexual, racial, cultural (etc.) differences. This presents a complex, embodied equation of gendered subjectivity that is less about balances of agency (girl power) and compliance (girl victims) than it is about contingent and ambiguous practices of identity. Girls' gendered agency is practiced within normative social, economic and political processes of creating and reproducing gendered identity. The constraints of gender and normative femininity are therefore always a factor in its production, expression and resistance. This Special Issue is concerned with how gender difference and femininity are re-made through normative, socially constraining often contradictory (schizoid) spaces of family, the media, school and popular culture. Though aspects of femininity are taken on as practices of self, they are still mutable, dynamic, immanent and open to transformation. In suggesting that gender is never separate from its various spatialities and contexts, we argue for complex theorizations of gendered agency and resistance that illuminate what is enabling and constraining, and how femininities are contingent and ambiguous.

\section{This Special Issue}

Valerie Hey's article in this issue engages with Angela McRobbie's recent book The Aftermath of Feminism: Gender, Culture and Social Change that 
we have referred to throughout this introduction. In it, Hey thinks through the new vocabulary the book offers for understanding late modernity's revised sexual and cultural politics. She provocatively suggests that if theory performs a politics of representation questions need to be asked about what happens to the theoretical status of class in McRobbie's accounting for post-feminism.

Michele Byers' paper offers an important class, ethnic and culturally specific analysis of contemporary U.S. girlhood in analyzing the figure of the Jewish American Princess. Using Bauman's distinction between Pariahs and Parvenus to think about the ambivalence of gendered Jewish American identities in contemporary culture, she suggests that Jewishness is always marked as Pariah, but that JAP 'excesses' as Parvenu may also be worn as a 'badge of resistance'.

Lisa Weems explores the performance art of international hip-hop artist M.I.A. to consider issues of agency and resistance in the context of post-colonial girlhood. Using a framework of feminist transnational praxis, Weems argues that M.I.A. is both cultural product and cultural producer in a larger global youthscape. Through a close reading of the song, 10 Dollar, Weems illustrates how M.I.A. is particularly useful for pushing the logic of both global studies of youth, and girlhood studies beyond their current logics.

The question of how minority girls in western countries use a variety of sophisticated strategies to negotiate their racialized identities in white peer culture is taken up in Mythili Rajiva's contribution to this Special Issue. Using empirical data from a set of qualitative interviews with second generation South Asian girls and women in Canada, Rajiva explores constructions of South Asian-ness and belonging in relation to the Canadian imaginary, and to global culture. She is interested in exploring how the strategies of resistance used by her informants produce both creative and painful possibilities for living with 'difference'.

Jessica Willis's article on agency, hybridity and transformation explores resistance as a multi-layered and relational negotiation of structures and discourses in girls' everyday lives. Her empirical research findings also suggest, however, that individual 'resistance' to dominant hetero-scripts of femininity emerged only at the level of the imaginary for tween girls, thus raising important questions for what this might mean in relation to feminist goals of collective resistance to 'gender oppression'. 
Cuban girls' cultural production as hip hop artists is the focus of Ardath Whynacht's article "Raperas of the NeoRevolución." The article sets this artistic production within the context of larger, hemispheric and economic processes and Whynacht makes the argument that predominantly AfroCuban girls are using hip hop culture to create a discourse that engages in a multi-generation dialogue with older women as well as powerful and assertive gendered identities. She argues that more so than their U.S. contemporaries, Cuban girls have used hip hop to raise questions about neo-liberal political culture and commodification of the recording industry.

Using the medium of music and performance, Peaches' artistry, as Marnina Gonick suggests in her review, puts to work many of the theoretical discussions of agency, resistance, the body, sexuality and gender discussed in this Special Issue. What is so compelling about her work is the way in which she both uses and transforms hyper-sexuality as a form of gender and sexual politics. Her lyrics, music, videos and onstage performances queers everyday notions of male/female binaries and humorously engages with what counts as the mainstream.

\section{References}

Braidotti, Rosi. 2006. Transpositions: On Nomadic Ethics. Cambridge: Polity Press.

Butler, Judith. 2006. "Response to Special Issue: Troubling identities: reflections on Judith Butler's philosophy for the sociology of education." British Journal of Sociology of Education 27, no. 4: 529-534.

Corrigan, Philip. 1979. Schooling the Smash Street Kids. London: Macmillan.

Davies, Bronwyn. 2000. (in)scribing body/landscape relations. New York: Altamira Press.

Davies, Bronwyn and Peter Bansel. 2007. "Neoliberalism and education." International Journal of Qualitative Studies in Education 20, no. 3: 247-259.

Gaunt, Kyra. 2006. Games Black Girls Play: Learning the Ropes from Double-dutch to Hip-hop. New York: New York University Press.

Gill, Rosalind. 2007. "Postfeminist Media Culture: Elements of a Sensibility" European Journal of Cultural Studies 10, no. 2: 147-166.

Gill, Rosalind. 2008. "Empowerment/sexism: Figuring female sexual agency in contemporary advertising." Feminism and Psychology 18, no. 1: 35-60.

Gonick, Marnina. 2006. "Between Girl Power and Reviving Ophelia: Constituting the Neoliberal Girl Subject." NWSA Journal 18, no. 2: 1-23.

Hall, Stuart and Tony Jefferson, eds. 1976. Resistance Through Rituals: Youth Subcultures in Post-War Britain. London: Hutchinson.

Hebdige, Dick. 1979. Subculture: The Meaning of Style. London: Methuen \& Co. 
Hernandez, Daisy and Bushra Rehman, eds. 2002. Colonize This! Young Women of Color on Today's Feminism. New York: Seal Press.

Kennelly, Jacqueline Joan. 2009. "Youth Cultures, Activism and Agency: Revisiting Feminist Debates." Gender and Education 21, no. 3: 259-272.

Klein, Naomi. 2000. No Logo: Taking Aim at the Brand Bullies. Toronto: Vintage Canada.

McRobbie, Angela. 1978. "The Culture of Working Class Girls”. Pp. 44-66 in Feminism and youth culture, ed. A.McRobbie, New York: Routledge.

McRobbie, Angela. 2000. Feminism and youth culture. $2^{\text {nd }}$ edition. New York: Routledge.

McRobbie, Angela. 2004. "Notes on Postfeminism and Popular Culture: Bridget Jones and the New Gender Regime." Pp. 3-14 in All about the Girl: Culture, Power and Identity, ed. A. Harris, New York: Routledge.

McRobbie, Angela. 2008. The Aftermath of Feminism: Gender, Culture and Social Change. London: Sage.

Renold, Emma, Jessica Ringrose, and Debbie Epstein. 2009. “The Social: Beyond Binaries, Thinking Nomadically." Paper presented at the 7th Gender and Education Association Conference, London, 25 to 27 March.

Taft, Jessica. 2004. "Girl Power Politics: Pop-Culture Barriers and Organizational Resistance.” Pp. 69-78 in All about the Girl: Culture, Power and Identity, ed. A. Harris. New York: Routledge.

Trinh, Min Ha. 1989. Woman, Native, Other. Bloomington: Indiana University Press.

Willis, Paul E. 1977. Learning to Labor: How Working Class Kids Get Working Class Jobs. New York: Columbia University Press. 